\title{
Associativismo e política no Rio de Janeiro do Segundo Império: o Clube Ginástico Português e o Congresso Ginástico Português*
}

Victor Andrade de Melo* Fabio de Faria Peres ${ }^{* * *}$

\section{RESUMO}

No Brasil do século XIX, em muitas cidades, inclusive na capital, portugueses criaram agremiaçóes dos mais diversos perfis. Considerando que essas iniciativas podem ser entendidas como uma estratégia de afirmação e conformação da comunidade lusitana no país, este artigo tem por objetivo analisar as trajetórias do Clube Ginástico Português e do Congresso Ginástico Português, procurando discutir tanto sua articulação com o cenário político do Segundo Império quanto os conflitos e tensóes existentes entre os lusitanos que na sociedade da Corte se estabeleceram. Para alcance do objetivo, como fontes foram utilizados periódicos publicados no Rio de Janeiro entre 1868, ano de fundação do Clube Ginástico Português, e 1889, ano em que as duas agremiaçóes se reconciliaram, depois de mais de uma década de conflitos. Além disso, foram consultados os estatutos disponíveis das duas sociedades.

Palavras-chave: associativismo; política; Segundo Império; portugueses; ginástica.

\section{ABSTRACT}

In many $19^{\text {th }}$ century Brazilian cities, including the capital, the Portuguese founded associations of various profiles. Considering that we can understand these initiatives as a strategy of statement and shaping of the Lusitanian community in Brazil, this article analyzes the trajectory of the Clube Ginástico Português and the Congresso Ginástico Português, and discusses their articulation with the political context of the Second Empire and the conflicts and tensions among the Portuguese who settled in Rio's society. The available statutes of the two clubs, and newspapers published in the city between 1868, when the Clube Ginástico

Artigo recebido em 13 de agosto de 2013 e aceito em 7 de fevereiro de 2014.

DOI - http://dx.doi.org/10.1590/2237-101X015028010

*A pesquisa que dá origem a este artigo é apoiada pela Capes, Faperj e CNPq.

** Doutor em educação física pela Universidade Gama Filho (UGF) e professor de história na Univesidade Federal do Rio de Janeiro (UFRJ). Rio de Janeiro, RJ, Brasil. E-mail: victor.a.melo@uol.com.br.

${ }^{* * *}$ Bolsista (Capes/Faperj) de pós-doutorado em história comparada na Universidade Federal do Rio de Janeiro. Rio de Janeiro, RJ, Brasil. E-mail: fabioperes@ymail.com. 
Associativismo e política no Rio de Janeiro do Segundo Império: o Clube Ginástico Português E O Congresso Ginástico Português

Victor Andrade de Melo e Fabio de Faria Peres

Português was founded, and 1889, when the two associations were reconciled, after more than a decade of conflict, were used as sources.

Keywords: associativism; polítics; Second Empire; Portugueses; gymnastics.

\section{Introdução}

Em 1883, a Gazeta Lusitana assim comentou o costume de criar agremiaçóes que os portugueses adotaram em muitas cidades brasileiras:

Incontestavelmente é digno de nota ver-se o espírito de associação de que são dotados os portugueses residentes no Brasil. Não podemos deixar de simpatizar com tão nobre sentimento que eleva o individuo à comunhão social e o faz por isso, identificar perante os seus compatriotas, como um ente útil à sociedade, congraçando a grande família portuguesa em um só princípio —o amor à pátria. ${ }^{1}$

Observa o jornalista que, entre tantas, algumas dessas associaçóes são "dedicadas ao cultivo da musica, ginástica etc.". Para ele, os lusitanos "procuram um passatempo útil e agradável ao mesmo tempo, demonstrando o espirito de uniáo de que é dotada a mocidade portuguesa".

Sugere ainda que o português tem claras diferenças se comparado a outros estrangeiros que no Brasil viviam. Estaria disposto a trabalhar intensamente e a criar raízes, sentindo-se em casa: "Ele parece quando muito que mudou de província, mas nunca que mudou de país".

A Gazeta Lusitana foi publicada entre os anos de 1883 e 1889. Embora a presença de lusitanos fosse significativa na imprensa fluminense, ${ }^{2}$ havia também semanários próprios da colônia, ${ }^{3}$ cujo principal intuito era defender os "interesses dos portugueses residentes no Brasil". ${ }^{4}$ Entende-se, assim, em parte, a postura elogiosa do periódico com o hábito dos patrícios de criar associações. ${ }^{5}$

\footnotetext{
${ }^{1}$ Gazeta Lusitana, 22 dez. 1883. p. 1.

${ }^{2}$ FERREIRA, Marie-Jo. Os portugueses do Brasil, atores das relaçôes luso-brasileiras, fim do século XIX - início do século XX. Rio de Janeiro: Arquivo da Cidade do Rio de Janeiro, 2007. Disponível em: <www0.rio.rj.gov. br/arquivo/pdf/quartas_no_arquivo/2007/palestra_MarieJoFerreira.pdf>. Acesso em: 8 jun. 2013.

${ }^{3}$ Segundo Maire-Jo Ferreira (ibid.), no Rio de Janeiro e em São Paulo, entre 1850 e 1950, houve mais de quarenta jornais dirigidos à comunidade portuguesa que vivia no Brasil.

${ }^{4}$ Gazeta Lusitana, 11 dez. 1883. p. 1.

${ }^{5}$ Por essa vinculação com a colônia portuguesa, por vezes esses periódicos sofreram perseguiçôes. No caso da Gazeta Lusitana, foi em diversas ocasiôes invadida por denúncias que fizera contra a violência da Guarda Nacional contra os patrícios (SILVA, Maria Manuela de R. de Sousa. Portugueses no Brasil: imaginário so-
} 
O associativismo dos portugueses, contudo, também chamou a atenção de nacionais. Em 1887, por exemplo, o assunto mereceu referências de um de nossos maiores dramaturgos, Artur Azevedo, que com seu olhar arguto o inseriu em uma de suas peças de revista, $O$ homem. ${ }^{6}$ Uma das cenas é totalmente dedicada a ironizar as estratégias de organização da colônia, ela mesma uma personagem, que assim dizia:

Que neste país tamanho

Uma coisa é ser estranho

E é outra ser português.

No fundo do coração

Pelo Brasil recebidos,

Nós somos irmãos queridos,

Não somos hóspedes, não.

A personagem "colônia portuguesa" sugere que se dedicava a contribuir para o progresso do país. Um indicador disso seria exatamente suas associaçóes, que atuavam em diferentes esferas. Uma vez mais o dramaturgo ironiza:

Eis a Beneficência, A minha glória, o meu eterno orgulho!

(...)

O Liceu Literário...

Vê como vai catita;

Não há colégio mais humanitário,

Nem mais cosmopolita,

Não faz questão de nacionalidade:

Para aprender ali, basta a vontade.

A Caixa de Socorros,

A Caridade a jorros!

O Real Clube Ginástico...

Inteligente, pândego, fantástico...

Este é o Retiro Literário... um ninho...

O Congresso Ginástico aparece...

O Congresso a que vem Martins de Pinho...

cial e táticas cotidianas (1880-1895). Acervo, Rio de Janeiro, v. 10, n. 2, p. 119, jul./dez. 1997). Utilizaremos alguns desses jornais no decorrer do artigo.

${ }^{6}$ Disponível em: <www.encontrosdedramaturgia.com.br/wp-content/uploads/2010/10/Artur-Azevedo-O-HOMEM.pdf>. Acesso em: 9 jun. 2013. 
Associativismo e política no Rio de Janeiro do Segundo Império: o Clube Ginástico Português e o Congresso Ginástico Português

Victor Andrade de Melo e Fabio de Faria Peres

Para entender melhor esse impulso associativista dos portugueses, de um lado devemos considerar que essa era uma ocorrência comum no Segundo Império, observável em vários âmbitos, com os mais distintos intuitos. Para Vitor Fonseca, ${ }^{7}$ as agremiaçóes eram espaços de sociabilidade que atendiam a necessidades específicas de certos grupos, ligadas a um exercício possível da cidadania, que tinha em conta os limites do jogo político da ocasiáo. Isto é, o crescimento do número de associaçôes não seria somente a expressão de um maior exercício (e expectativas) de direitos sociais, como também da construção de novas posturas políticas, que materializavam certa visão de mobilização, indícios de uma ideia de cidadania em construção.

De outro lado, é importante ter em conta que, de fato, entre os estrangeiros, era distinta a situação dos lusitanos que no país se estabeleceram. Devemos lembrar que, muito embora a questão da cidadania tenha sido objeto de controvérsias no pós-independência, ela fora definida, provisoriamente, já em janeiro de $1823 .{ }^{8}$ Como cidadãos eram admitidos os portugueses já residentes e os que chegassem com o intuito de se estabelecerem "pacificamente neste país", desde que se apresentassem à câmara municipal do respectivo porto de entrada e prestassem "solene juramento de fidelidade à causa do Brasil e ao seu Imperador".

Posteriormente, na Constituinte, a discussão do tema foi marcada por tensóes em torno do Projeto de Lei do deputado Francisco Muniz Tavares, que propunha a restrição das possibilidades de naturalização. Entre os pontos debatidos, encontravam-se as provas de adesão à causa da independência, o poder do governo expulsar portugueses que assumissem atitudes suspeitas e a instituição do prazo de sete anos de residência como critério para a obtenção da cidadania brasileira.

Após a dissolução da Assembleia de 1823, todavia, tais limitaçôes não encontraram eco. De fato, a Constituição de 1824 estabeleceu que os portugueses (e suas "possessôes") que, residindo no Brasil quando da proclamação da independência, tivessem aderido à causa eram considerados cidadãos brasileiros, ainda que com restrições no que tange à participação política. ${ }^{9}$

Mesmo com a independência, seguiu intenso o fluxo migratório de Portugal para o Brasil. Nesse cenário, "o Rio, Corte Imperial e capital da República, teve preferência como uma espécie de continuação do sonho lotérico do século XVIII de fazer fortuna nas Gerais". ${ }^{10}$

\footnotetext{
${ }^{7}$ FONSECA, Vitor Manoel Marques da. No gozo dos direitos civis: associativismo no Rio de Janeiro, 19031916. Niterói: Muiraquitã, 2008.

${ }^{8}$ BRASIL. Decreto de 14 de janeiro de 1823. Sobre as condiçóes com que podem ser admitidos no Brasil os súditos de Portugal. Disponível em: <www2.camara.leg.br/legin/fed/decret_sn/anterioresa1824/decreto-38719-14-janeiro-1823-567488-publicacaooriginal-90821-pe.html>. Acesso em: 26 fev. 2014.

${ }^{9}$ Para mais informaçóes, ver: VIEIRA, Martha Victor. Antilusitanismo, naturalização e disputas pelo poder no Primeiro Reinado. MÉTIS: história \& cultura, v. 5, n. 10, p. 87-99, jul./dez. 2006.

${ }^{10}$ LESSA, Carlos. Rio, uma cidade portuguesa? In: LESSA, Carlos (Org.). Os Lusíadas na aventura do Rio moderno. Rio de Janeiro: Record; Faperj, 2002. p. 21-62. p. 27.
} 
Associativismo e política no Rio de Janeiro do Segundo Império: o Clube Ginástico Português e o Congresso Ginástico Português

Victor Andrade de Melo e Fabio de Faria Peres

Em 1890, quando a cidade possuía cerca de 500 mil habitantes, cerca de 100 mil eram portugueses ${ }^{11} 20 \%$ da populaçáo, portanto. Era o grupo majoritário de imigrantes. ${ }^{12}$

Nesse contexto, de um lado havia posicionamentos que de alguma forma beneficiavam os portugueses, como aponta Seyferth:

(...) grupos nacionalistas apregoavam o perigo de uma concentração de estrangeiros não assimilados, culturalmente muito distintos e não católicos, no sul do país. Não eram necessariamente contrários à colonização estrangeira, mas queriam imigrantes (categoria que passou a ser usada com mais frequência) de origem latina. Para eles havia uma tradição a ser respeitada e o Brasil devia fazer parte da civilização ocidental como país de formação latina, católica e de língua portuguesa. Quais as implicaçôes desse argumento reportado à nação muito mais do que aos interesses do Estado na imigração? Certamente muda o perfil do imigrante ideal, que não é mais o europeu em geral, mas os latinos mais próximos dos brasileiros — portugueses, italianos e espanhóis. ${ }^{13}$

Devemos lembrar que, no Brasil do século XIX, muitos portugueses gozavam de prestígio, relacionado a suas posiçóes e seu sucesso no comércio e na indústria. Segundo Freitas Filho, naquele momento as elites brasileiras estavam mais envolvidas com o setor agropecuário, com as profissões liberais e com cargos políticos e administrativos. ${ }^{14}$

De outro lado, entre os populares muitas foram as manifestações de contestação, mais ou menos violentas, origem de uma ironia que vai se perpetuar até os dias de hoje. Os lusitanos eram considerados interesseiros e exploradores, criticados por privilegiarem os que vinham de Portugal em detrimento dos brasileiros. ${ }^{15} \mathrm{Na}$ verdade, poucos não eram os incômodos com seu protagonismo na alta ou baixa esfera social.

Mesmo que "ser brasileiro" ou "ser português" adquirisse sentidos particulares que se articulavam a conjunturas políticas e econômicas mais amplas, não se restringindo, portanto,

\footnotetext{
${ }^{11}$ Ibid.

${ }^{12}$ Para mais informações, ver: CERVO, Amado Luiz; MAGALHĀES, José Calvet de. Depois das caravelas: as relaçôes entre Portugal e Brasil, 1808-2000. Brasília: EdUnb, 2000.

${ }^{13}$ SEYFERTH, Giralda. Imigrantes, estrangeiros: a trajetória de uma categoria incômoda no campo político. In: REUNIÃO BRASILEIRA DE ANTROPOLOGIA, 26, 2008, Salvador. Anais... Salvador, UFBA, 2008. p. 1-20 p. 9. (Anais eletrônicos).

${ }^{14}$ FREITAS FILHO, Almir Pita. A colônia portuguesa na composição empresarial da cidade do Rio de Janeiro no final do século XIX e início do XX. In: LESSA, Carlos (Org.). Os Lusíadas na aventura do Rio moderno. Rio de Janeiro: Record; Faperj, 2002. p. 163-198.

${ }^{15}$ Para mais informaçóes, ver: RIBEIRO, Gladys Sabina. A liberdade em construção. Identidade nacional e conflitos antilusitanos no Primeiro Reinado. Rio de Janeiro: Faperj; Relume Dumará, 2002; e ROWLAND, Robert. A cultura brasileira e os portugueses. In: BASTOS, Cristiane; ALMEIDA, Miguel Vale de; FELDMAN-BIANCO, Bela (Org.). Trânsitos coloniais: diálogos críticos luso-brasileiros. Campinas: Editora Unicamp, 2007. p. 397-410.
} 
Associativismo e política no Rio de Janeiro do Segundo Império: o Clube Ginástico Português e o Congresso Ginástico Português

Victor Andrade de Melo e Fabio de Faria Peres

à naturalidade per si, a legitimação da ideia de nação foi marcada, de acordo com Rowland (2003), pela coexistência, com variações, de três estratégias discursivas:

A primeira definia a identidade do Brasil por oposiçẫo à antiga metrópole, procurando encontrar na oposição a Portugal uma explicação e justificaçáo da Independência; a segunda, inversamente, definia-a em termos da singularidade do novo país, que se exprimia na sua natureza tropical e paisagem luxuriante e na cultura e tradiçôes das populaçôes indígenas; a terceira, por fim, procurava definir para a nova nação um projeto ou missão que consistiria, através da combinação de elementos europeus e americanos, na edificação e afirmação, através do Estado e da coroa, de uma civilização europeia nos trópicos. ${ }^{16}$

A presença de portugueses em um cenário em que o país pretendia se afirmar como ente independente era mesmo algo um tanto ambíguo. De um lado, havia louvaçôes aos laços em comum entre Brasil e Portugal, a uma tradiçáo que tinha se enraizado no cotidiano. De outro lado, era isso mesmo que incomodava os que acreditavam que a construção da naçáo "civilizada" necessariamente deveria passar pelo abandono da herança colonial.

A criação de agremiaçóes, assim, pode ser entendida como uma estratégia de afirmação e conformação da comunidade lusitana. Atendia tanto à necessidade de auto-organização, para melhor encarar os problemas enfrentados no Brasil e para celebrar a relaçáo com a pátria distante, quanto ao desejo de demonstrar à sociedade brasileira o valor da colônia portuguesa, sendo também uma forma de intervenção política. Como bem resume Ferreira:

Essas associações desempenharam entâo um papel bastante importante na vida social, cultural e desportiva da sociedade brasileira. Elas compensavam a falta de assistência e de ajuda das autoridades consulares portuguesas aos imigrantes portugueses no Brasil e assumiram a função de realizar trocas culturais entre Portugal e Brasil, na ausência de uma política cultural entre os governos dos dois países. ${ }^{17}$

Entre tantas associaçóes fundadas por lusitanos, podemos destacar o Gabinete Português de Leitura (criado em 1837), a Sociedade Portuguesa de Beneficência (1840), a Caixa de Socorros D. Pedro V (1863), o Liceu Literário Português (1868) e, nosso objeto de estudo, duas sociedades ginásticas: o Clube Ginástico Português (1868) e o Congresso Ginástico Português (1874).

Não poucas vezes essas instituiçóes atraíram reconhecimento para os portugueses no Brasil estabelecidos. O hospital da Beneficência chegou a ser considerado táo importante

\footnotetext{
${ }^{16}$ ROWLAND, Robert. Patriotismo, povo e ódio aos portugueses: notas sobre a construção da identidade nacional no Brasil independente. In: JANCSÓ, István (Org.). Brasil: formação do Estado e da Nação. São Paulo: Hucitec/Unijuí/Fapesp, 2003. p. 365-388. p. 366.

${ }^{17}$ FERREIRA, Marie-Jo. Os portugueses do Brasil, atores das relaçôes luso-brasileiras, fim do século XIX — inicio do século $X X$, op. cit.
} 
Associativismo e política no Rio de Janeiro do Segundo Império: o Clube Ginástico Português e o Congresso Ginástico Português

Victor Andrade de Melo e Fabio de Faria Peres

quanto a Santa Casa de Misericórdia. O Liceu era valorizado pelas contribuiçôes à educação. As agremiaçôes recreativas também eram constantemente elogiadas: "A colonia portuguesa tem-se assinalado no nosso reconhecimento por serviços importantes em todo o império; mas na Corte seus serviços são relevantes (...). O Club e o Congresso Ginástico Português, além dos edifícios que funcionam, prestam serviços dignos de nota". ${ }^{18}$

Além disso, há ainda uma dimensão que precisa ser ressaltada, inclusive por ser clara nas agremiaçóes ginásticas: "A criação e manutenção das associaçôes servia, também, como legitimação e testemunho do sucesso alcançado por seus promotores no país que os acolhera. Era a materialização sociocultural de uma trajetória econômico-financeira bem-sucedida". ${ }^{19}$

Por que, todavia, foram criadas duas agremiaçóes ginásticas de portugueses na sociedade da Corte? Sinal de que era grande a colônia ou de que havia fissuras na sua conformação, dimensóes que podem mesmo estar articuladas? Este artigo tem por objetivo analisar as trajetórias do Clube Ginástico Português e do Congresso Ginástico Português, procurando discutir tanto sua articulação com o cenário político do Segundo Império quanto os conflitos e tensôes existentes entre lusitanos que no Rio de Janeiro se estabeleceram.

Os clubes funcionavam em um contexto em que, finda a Guerra do Paraguai, a monarquia chegara a seu auge, mas também caminhava para seu fim. ${ }^{20} \mathrm{O}$ abolicionismo se tornou uma questão fulcral, em maior ou menor grau articulado, ainda que não necessariamente de forma coincidente, com a assunção de propostas republicanas. Os militares, notadamente do Exército, ocupavam um novo espaço político na sociedade, fomentado ainda mais pela adesão de jovens a ideais positivistas (que rejeitavam a escravidão e apoiavam a república). Além disso, percebe-se uma maior multifacetação social, com um melhor delineamento dos estratos médios.

Para alcance do objetivo, como fontes, além dos estatutos disponíveis das duas sociedades, foram utilizados periódicos publicados no Rio de Janeiro entre 1868, ano de fundação do Clube Ginástico Português, e 1889, ano em que as duas agremiaçôes se reconciliaram, depois de mais de uma década de conflitos. Cabe observar que os jornais e as revistas usados possuíam diferentes perfis, merecendo nossa observação sobre suas características quando julgamos necessário. Todavia, deve-se perceber que era alto o grau de heterogeneidade e mudanças numa imprensa que ainda tentava melhor se estruturar. ${ }^{21}$ Nesse sentido, nem sempre o olhar do cronista citado pode ser subsumido ao caráter majoritário do veículo analisado.

Com este estudo espera-se lançar um olhar sobre algumas importantes dimensóes que marcavam o Rio de Janeiro do século XIX: o surgimento de novas práticas sociais, típicas

\footnotetext{
${ }^{18}$ O Paiz, 8 ago. 1886. p. 2. Esse periódico tinha forte relação com a colônia lusitana.

${ }^{19}$ FREITAS FILHO, Almir Pita. A colônia portuguesa na composição empresarial da cidade do Rio de Janeiro no final do século XIX e início do XX, op. cit. p. 172.

${ }^{20}$ CARVALHO, José Murilo. A vida política. In: CARVALHO, José Murilo (Coord.). História do Brasil nação (1808-2010) — volume 2 - A construção nacional (1830-1889). Rio de Janeiro: Objetiva, 2012. p. 83-129. ${ }^{21}$ SODRÉ, Nelson Werneck. História da imprensa no Brasil. São Paulo; Porto Alegre: Intercom; Edipucrs, 2011.
} 
Associativismo e política no Rio de Janeiro do Segundo Império: o Clube Ginástico Português e o Congresso Ginástico Português

Victor Andrade de Melo e Fabio de Faria Peres

de um contexto em que emergiam discursos de modernidade; a articulação entre associativismo e política; o papel desempenhado por portugueses em um momento importante da constituição da nação independente.

\section{Clube Ginástico Português}

O Clube Ginástico Português foi fundado em 1868, antes, portanto, da pioneira sociedade ginástica criada em Portugal, o Ginásio Clube Português (1875). ${ }^{22}$ De acordo com o sítio da agremiação, ${ }^{23}$ que permanece ativa até os dias de hoje, os primeiros estatutos teriam sido aprovados, pelo chefe de polícia da Corte, em 1869.

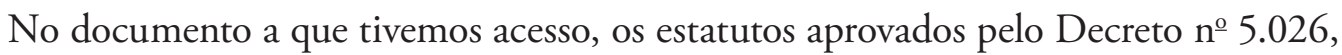
de 24 de julho de 1872, ${ }^{24}$ João José Ferreira da Costa e Antônio José Ferreira da Costa são reconhecidos como sócios fundadores e beneméritos, por tal condição podendo "usar como distintivo uma fita azul e branca com uma medalha pendente ao pescoço, tendo gravada na mesma a data da fundaçáo do club, de um lado e de outro - Club Ginástico Português".

Segundo o sítio do clube, o primeiro seria oficial de correio (na verdade, correeiro, isto é, responsável por trabalhar o couro, confeccionando tanto obras de decoração quanto produtos para cavalos) e o segundo, dono de uma venda na rua do Hospício (atual Buenos Aires), onde teria sido fundada a agremiação, local no qual os primeiros associados faziam seus exercícios ginásticos.

Segundo essa versão, a agremiação teria uma origem popular. Devemos nos perguntar, contudo, como teria sido possível pessoas com esse perfil já estarem envolvidas com a ginástica, cuja prática e, sobretudo, o ensino ainda não eram totalmente vulgarizados na vida social do Império.

Embora a ginástica já estivesse inserida de forma múltipla em diferentes instituições da Corte - algumas escolas, instituiçôes militares e, em particular, nos circos e teatros, onde era uma atração que agradava a uma sociedade que cada vez mais valorizava os divertimentos públicos - , condiçóes específicas e concretas do Império dificultavam uma maior estru-

\footnotetext{
${ }^{22} \mathrm{O}$ caso da conformação da ginástica e do esporte em Portugal do século XIX ainda não foi largamente debatido, embora já existam alguns estudos sobre o tema. Alguns pesquisadores argumentam que a fraca adesão inicial às práticas, naquele país, tem relação com as suspeitas e distanciamentos de certos parâmetros da modernidade. Para mais informaçóes, ver: HASSE, Manuela. O divertimento do corpo: corpo, lazer e desporto na transição dos séculos XIX e XX, em Portugal. Lisboa: Temática, 1999; e MELO, Victor Andrade de. Que modernidade? O esporte em Os maias (Eça de Queirós, 1888). Aletria: Revista de Estudos de Literatura, v. 22, n. 2, p. 201-217, maio/ago. 2012.

${ }^{23}$ Disponível em: <www.clubeginastico.com.br/>. Acesso em: 20 jun. 2013.

${ }^{24}$ BRASIL. Decreto $n^{0}$ 5.026, de 24 de julho de 1872. Aprova os estatutos da associação denominada Club Ginástico Português. Disponível em: <www2.camara.leg.br/legin/fed/decret/1824-1899/decreto5026-24-julho-1872-551233-norma-pe.html>. Acesso em: 26 maio 2013. É possível que se trate dos mesmos estatutos de 1869, mas não conseguimos confirmar tal informação.
} 
Associativismo e política no Rio de Janeiro do Segundo Império: o Clube Ginástico Português e o Congresso Ginástico Português

Victor Andrade de Melo e Fabio de Faria Peres

turação do seu ensino-aprendizado. A relação entre ideias e formação social fez com que a prática adquirisse alguns contornos particulares no Rio de Janeiro do século XIX. ${ }^{25}$

Além disso, encontramos informações contraditórias. Sabemos que certo João José Ferreira da Costa já vinha atuando como mestre na Sociedade Francesa de Ginástica. ${ }^{26}$ Mais ainda, tratava-se de uma família que tinha algum destaque na sociedade política do Império. Há outro indicador que deve ser levado em conta: o primeiro presidente do clube, eleito em 1869, foi, segundo o sítio do clube, Manuel Mariano Ribeiro, membro ativo da loja maçônica Grande Oriente do Brasil. É pouco provável que tenha sido de família humilde.

De toda forma, muitos comerciários parecem ter integrado as fileiras do Clube Ginástico. Essa referência apareceu em vários momentos. Em novembro de 1870, por exemplo, um jornalista, que elogia os avanços que a agremiação "tem feito no curto espaço de tempo que consta de existência", ${ }^{27}$ observou que "um bom número de empregados do comércio encontra ali noturnamente algumas horas de salutar e divertido exercício e a confraternizaçáo da classe". As roupas e as posturas dos associados eram apresentadas como "simples e elegantes".

Alguns anos mais tarde, quando foi inaugurada uma nova sede, ao celebrar a conquista, uma vez mais a diretoria lembra do grupo social majoritariamente representado: "É uma glória para todos os srs. sócios, é um triunfo dizer-se que uma sociedade recreativa, composta, na máxima parte, da mocidade empregada no comércio, pudesse levar a efeito a construção deste edifício que é, podemos dizer, o único de seu gênero no Brasil". ${ }^{28} \mathrm{~A}$ agremiação, a essa altura, ainda reforçava essa identidade de categoria.

Devemos ter em conta que era bastante diverso o quadro de comerciários na ocasiáo. De um lado, de fato, os portugueses, que eram proprietários de grande parte dos negócios, admitiam mais patrícios do que brasileiros. De outro lado, "a profissão, no Rio de Janeiro, incluía um espectro amplo de funçôes que atendiam a uma escala hierárquica". ${ }^{29}$ Havia um grande número de cargos e remuneraçóes, podendo ser, em linhas bem gerais, divididos em "alto comércio" e "baixo comércio", de acordo com a complexidade das açôes e do volume financeiro mobilizado.

Essas diferenças, veremos, eram perceptíveis no Clube Ginástico e no Congresso Ginástico. De toda forma, é possível sugerir que os grupos envolvidos com essas agremiaçóes,

\footnotetext{
${ }^{25}$ Para mais informaçôes, ver: MELO, Victor Andrade de; PERES, Fabio de Faria. O corpo da nação: posicionamentos governamentais sobre a educação física no Brasil monárquico. História, Ciências, Saúde Manguinhos, Rio de Janeiro, 2014. No prelo. PERES, Fabio de Faria; MELO, Victor Andrade de. A introdução da ginástica nos clubes do Rio de Janeiro do século XIX. Movimento, Porto Alegre, 2014. No prelo.

${ }^{26}$ Fundada em 1863, foi antecedida pela Sociedade Alemã de Ginástica, criada em 1859.

${ }^{27}$ Diário de Notícias, 3 nov. 1870. p. 2. Trata-se do periódico que foi dirigido por A. Clímaco dos Reis. Mesmo com a intensa movimentação política do momento, o jornal procurava se apresentar como alheio às questôes partidárias. O redator era português e já atuara na mesma função em seu país de origem.

${ }^{28}$ A Instrução Pública, 22 dez. 1872. p. 332.

${ }^{29}$ POPINIGIS, Fabiane. Proletários de casaca: trabalhadores do comércio carioca (1850-1911). Campinas: Editora da Unicamp, 2007. p. 34.
} 
Associativismo e política no Rio de Janeiro do Segundo Império: o Clube Ginástico Português e o Congresso Ginástico Português

Victor Andrade de Melo e Fabio de Faria Peres

mesmo que com parâmetros distintos, tinham em conta um processo típico de estratos intermediários: "Em meados da década de 1850, essas pessoas teriam, segundo ele (Owensby), encontrado uma maneira de diferenciarem-se das classes inferiores, mas também, e sobretudo, de afirmarem-se perante as elites. A importância de ser culto seria uma guinada das classes médias na busca de status e ascensão social" ${ }^{30}$ Esse processo era marcado por uma ambiguidade observável na classe do comércio:

Por um lado, o caixeiro era o trabalhador empenhado, fiel à mentalidade de comerciante, defensor dos interesses do patrão, e, por isso, muito pouco tempo tinha para si mesmo e para a vida "fútil" das diversóes que a rua oferecia. Por outro, apresenta-se o caixeiro como um pastiche burguês, aspirando a uma condição social superior, preocupado com o trajar e com assuntos reservados aos privilegiados da sociedade; a literatura e a política. ${ }^{31}$

Além de ter em conta os diferentes perfis dos trabalhadores do comércio, majoritariamente portugueses, o Clube Ginástico também procurava se equilibrar entre as referências ao Brasil e a Portugal, concedendo especial atenção aos símbolos do país ibérico. Normalmente abria suas cerimônias, pelo menos até a proclamação da República, com a execução dos hinos das duas naçôes, exemplo de sua dupla vinculação. Constantemente comemoravam-se as datas importantes das duas coroas, ainda mais festivamente as da portuguesa.

Bastante simbólica, nesse sentido, foi a cerimônia em que se comemorou, em 1876, a concessão ao clube, por parte da Coroa portuguesa, do título de "Real", pelos serviços prestados à cultura e à colônia lusitana. ${ }^{32}$ Presentes estavam Matias de Carvalho (ministro de Portugal no Brasil), o barão de Wildik ${ }^{33}$ (cônsul-geral), além de representantes do Liceu Literário, da Caixa de Socorros de D. Pedro V e da Beneficência Portuguesa. Tratou-se de uma completa celebração lusitana em terras brasileiras.

Muitos foram os representantes do corpo diplomático e as personalidades importantes da colônia portuguesa no Brasil, ou de Portugal que estavam no Brasil, que visitaram a agremiação, por vezes até mesmo se tornando sócios. Não poucas vezes receberam fartos agradecimentos e reconhecimento pela ajuda dada ao seu funcionamento.

Os diplomatas também tinham a agradecer aos clubes portugueses, já que esses os auxiliavam na execução de suas tarefas. Não surpreende saber que as agremiações chegaram a ser

\footnotetext{
${ }^{30}$ Ibid., p. 55.

${ }^{31}$ Ibid, p. 183.

${ }^{32} \mathrm{O}$ clube passou a se chamar Real Clube Ginástico Português. A mudança foi aprovada pelo seguinte decreto: BRASIL. Decreto $n^{\circ} 6.443$, de 30 de dezembro de 1876. Aprova a alteração do nome do Club Ginástico Português. Disponível em: <www2.camara.leg.br/legin/fed/decret/1824-1899/decreto-6443-30-dezembro-1876-549907-publicacaooriginal-65444-pe.html>. Acesso em: 26 maio 2013.

${ }^{33}$ Tratava-se de Pedro Afonso de Figueiredo, que chegou a escrever o livro Guia do cidadão português no Império do Brasil, ou Compêndio dos direitos e deveres dos portugueses residentes no Império, lançado pela Tipografia da Gazeta de Notícias, em 1884.
} 
Associativismo e política no Rio de Janeiro do Segundo Império: o Clube Ginástico Português E o Congresso Ginástico Português

Victor Andrade de Melo e Fabio de Faria Peres

agraciadas com comendas de Portugal: o Congresso Ginástico Português com a de Freixo de Espada à Cinta e o Clube Ginástico Português com essa e a Cruz da Torre dos Clérigos, todas da Ordem de Cristo, uma sociedade religiosa e militar criada em 1319.

Nessa interface entre ser brasileiro e português, o clube foi ganhando notoriedade. Vejamos como um jornalista ressaltou a importância da ginástica e as contribuiçôes da agremiação por ocasião da inauguração da nova sede: "Embora geralmente sadia e forte, a mocidade portuguesa não pôde eximir-se da influência de sua raça e por isso os sócios do Club Ginástico souberam não manter-se exclusivamente no terreno simples do exercício corpóreo". ${ }^{34} \mathrm{O}$ Vida Fluminense foi também categórico: "O novo edifício é um dos mais vastos e elegantes desta Corte. Se excetuarmos o do Cassino Fluminense, não há no Rio saláo que possa ombrear em dimensóes com o do Club Ginástico". ${ }^{35}$ Não era um elogio pequeno: o Cassino era uma das mais importantes agremiaçôes da capital (e talvez mesmo do país). ${ }^{36}$

Para o jornalista de $O$ Mosquito, "nunca sociedade alguma fez tanto em tão poucos anos" ${ }^{37}$ Sua grande contribuição seria o "desenvolvimento físico do sexo forte, que apesar de forte está ficando raquítico e enfezado como um sibarita”. Nesse sentido, elogia a nova sede pela "singeleza arquitetônica que faz recordar, ainda que vagamente, a austera majestade dos antigos anfiteatros". Para o cronista, teria mais a feição de "um templo do que a de um recinto de divertimentos". É digna de destaque a representação construída: vinculava-se o clube a algo mais do que o puro entretenimento, teria uma clara utilidade social.

Devemos ter em conta que uma parte dessas posiçóes se articulava com o que sugere Popinigis: "A construção de um perfil de bons moços trabalhadores para os caixeiros tinha como funçâo assim mantê-los na legalidade e afastá-los do movimento operário radical". ${ }^{38}$ Uma parte dos empregados do comércio adotava mesmo esses discursos como forma de estabelecer relação com os patróes e o governo, a fim de obter ganhos em suas reivindicaçóes trabalhistas. De toda forma, isso não significará a ausência de envolvimento com movimentaçôes políticas. Veremos como os clubes acolheram algumas dessas iniciativas, e é fato que os comerciários foram ativos em muitas das questôes ocorridas nos anos finais do Império e anos iniciais da República.

Outra parte dos discursos tinha mesmo a ver com a adesão a ideais modernos, valorizados por certos setores da Sociedade da Corte. Logo, aliás, a agremiação passou a ser frequentada por pessoas de vários círculos sociais. Vejamos como é uma das nominalmente citadas pelo colunista de O Mosquito, que elogiava "a grande quantidade de festas musicais

\footnotetext{
${ }^{34}$ Diário de Notícias, 3 nov. 1872. p. 1.

${ }^{35}$ Vida Fluminense, 9 nov. 1872. p. 1192.

${ }^{36}$ Para mais informaçóes sobre o Cassino Fluminense, ver: NEEDELL, Jeffrey D. Belle Époque tropical. São Paulo: Companhia das Letras, 1993.

37 O Mosquito, 9 nov. 1872. p. 3.

${ }^{38}$ POPINIGIS, Fabiane, Proletário de Casaca, op. cit., p. 131.
} 
Associativismo e política no Rio de Janeiro do Segundo Império: o Clube Ginástico Português e o Congresso Ginástico Português

Victor Andrade de Melo e Fabio de Faria Peres

e dançantes" que havia no Rio de Janeiro, segundo ele responsável por "não saber a gente como se há de virar para ir a toda a parte": "É o baile do Club Ginástico Português por um lado, o sarau do Mozart pelo outro, o grande concerto da Filarmônica no saláo do Cassino, e que sei eu!". 39

Não surpreende que a agremiação tenha passado a figurar nas ediçôes de periódicos que, adotando uma linguagem mais descontraída, bem como o uso de quadrinhos e caricaturas, abordavam os fatos do cotidiano, a vida social, política e cultural da cidade, sempre com um olhar atento e irônico, como Vida Fluminense, O Mosquito e O Mequetrefe. ${ }^{40}$ Considerada como uma das grandes sociedades da ocasião, o Clube Ginástico passou a integrar com honras o mundo fashionable da Corte.

O clube português sempre promoveu um grande número de atividades: aulas de ginástica, esgrima e música; saraus e bailes; reunióes cotidianas na sede; passeios campestres. A agremiação buscava também se exibir publicamente nas mais diferentes ocasiōes. Um interessante exemplo foi a cerimônia de benção de seu estandarte, realizada solenemente na igreja do Senhor Bom Jesus do Calvário. ${ }^{41} \mathrm{O}$ pavilhão, aliás, foi produzido por Venâncio Inácio da Costa, importante artista, e exibido na Notre Dame de Paris, um dos maiores e mais prestigiosos magazines da cidade, situado à rua do Ouvidor. ${ }^{42}$

Outra atividade que aumentava sua visibilidade era a promoção de festas de caridade, tendo em conta as mais distintas causas, sob a forma de quermesse, apresentação ou bando precatório (um desfile público no qual se recolhiam donativos para alguma causa). O clube também procurava colaborar com as iniciativas de outras agremiaçóes assistenciais, especialmente com as da Sociedade de Beneficência Portuguesa, com a qual mantinha estreita relação.

Nessas ocasióes, não poucas vezes o clube explicitou sua dupla vinculação. Por exemplo, em março de 1871, os recursos obtidos com uma festividade beneficente foram divididos entre a Caixa de Socorros de D. Pedro V, uma instituição de cariz lusitano, e o Asilo dos Inválidos da Pátria, entidade nacional que atuava com os que lutaram na Guerra do Paraguai. ${ }^{43}$

Pelos jornais, muitos foram os elogios a essa iniciativa. L. Guimarães Júnior, na coluna "Revista de Domingo", o folhetim do Diário do Rio de Janeiro, exaltou: "Das associaçôes formadas há pouco tempo entre nós, há uma que merece a maior atenção e agasalho, não só pelo fim útil a que se dirigem os associados, como pelas provas de generosidade e caridade

\footnotetext{
${ }^{39}$ O Mosquito, 4 set. 1875 . p. 4.

${ }^{40}$ Nos dois primeiros periódicos, atuou um dos personagens célebres da imprensa no Império: Angelo Agostini (SODRÉ, Nelson Werneck. História da imprensa no Brasil, op. cit.).

${ }^{41}$ Era um importante templo, destruído quando da construção da avenida Presidente Vargas (ficava na rua do Sabão/General Câmara). A igreja hoje se localiza no bairro da Tijuca.

${ }^{42}$ Diário de Notícias, 14 dez. 1870. p. 1.

${ }^{43}$ Diário de Notícias, 12 mar. 1871. p. 1.
} 
Associativismo e política no Rio de Janeiro do Segundo Império: o Clube Ginástico Português e o Congresso Ginástico Português

Victor Andrade de Melo e Fabio de Faria Peres

que tem posto em prática”. ${ }^{44} \mathrm{Na}$ verdade, esses eventos eram sempre louvados. Valorizava-se "a ideia generosa que promove a festa", "tão útil e nobre pensamento". 45

Com tamanha presença social, o Clube Ginástico passou a ser muito procurado para a realização de reuniôes de diferentes grupos - recreativos, religiosos, esportivos, beneficentes, muitos deles agremiaçóes portuguesas. Essa prática se tornou comum no decorrer dos anos: as sociedades mais estruturadas cediam suas instalaçóes para algumas congêneres, sinal da fraternidade que entre elas existia.

O clube sediou muitos encontros de natureza política. Alguns dos assuntos candentes no Segundo Império de alguma forma passaram por seus salóes. Por exemplo, em março de 1879, por lá se reuniram oficiais da Armada e do Exército, nomeando uma comissão que se encarregou de defender os interesses dos militares. ${ }^{46}$ Já em maio de 1881, a reuniáo foi destinada a discutir a participação da categoria no pleito eleitoral, situando-se o debate entre os que achavam que se deveria apresentar um só concorrente, para garantir ao menos um representante na Câmara, e os que pensavam ser melhor lançar várias candidaturas. Dirigida pelo almirante Joaquim Raimundo de Lamare, ${ }^{47}$ contou com cerca de quinhentos presentes, decidindo-se ao final por apoiar dois candidatos: o tenente-coronel (futuramente general) Catão Roxo (do Exército) e o chefe de Divisão (futuramente almirante) Silveira da Motta (da Armada). ${ }^{48}$

Devemos lembrar que se tratou de um momento em que as Forças Armadas passaram a se posicionar mais explicitamente acerca das questóes nacionais, tanto nos seus fóruns e periódicos específicos, como O Soldado e a Tribuna Militar, quanto na imprensa em geral. ${ }^{49}$ Já havia uma geração de militares que dedicava maior "lealdade à corporação do que aos partidos, ou mesmo ao regime", sendo capaz de "enfrentar a elite civil dos bacharéis". ${ }^{0}$

Esse novo protagonismo dos militares também se articulava com uma das mais efervescentes questôes dos anos finais do Império: a extinção da escravatura. O Clube Ginástico acolheu reunióes de grupos abolicionistas. Por exemplo, em sua sede foram realizados os

\footnotetext{
${ }^{44}$ Diário do Rio de Janeiro, 2 abr. 1871. p. 1. Esse periódico foi relançado em 1860, tornando-se um dos mais populares e combativos da cidade, contando com a colaboração de importantes personagens como Quintino Bocaiúva e Machado de Assis. Notabilizou-se por sua qualidade e pelo olhar atento que lançou sobre as mudanças na sociedade da Corte (SODRÉ, Nelson Werneck. História da imprensa no Brasil, op. cit.).

${ }^{45}$ Diário do Rio de Janeiro, 13 ago. 1871. p. 2.

${ }^{46}$ O Repórter, 15 mar. 1879. p. 1.

${ }^{47}$ Importante personagem do Império, foi deputado, senador, presidente de província e ministro da Marinha, entre outros cargos que ocupou.

${ }^{48}$ Gazeta de Notícias, 7 maio 1881. p. 1. Esse periódico marcou época por suas posiçóes liberais e por abrir denotado espaço para a literatura, inclusive escritos de portugueses, como Eça de Queirós e Ramalho Ortigão. Graças à ação de Ferreira Araújo, o jornal tinha grande relação com a cultura de Portugal (MINÉ, Elza. Ferreira de Araújo, ponte entre o Brasil e Portugal. Via Atlântica, São Paulo, n. 8, p. 221-229, dez. 2005).

49 SCHULZ, John. O Exército na política: origens da intervenção militar, 1850-1894. São Paulo: Edusp, 1994.

${ }^{50}$ CARVALHO, José Murilo. A vida política, op. cit. p. 123.
} 
Associativismo e política no Rio de Janeiro do Segundo Império: o Clube Ginástico Português E O CONGRESSO GinÁstico PORTUguês

Victor Andrade de Melo e Fabio de Faria Peres

ensaios para um festival promovido, em maio de 1881, para angariar fundos para a causa. ${ }^{51}$ Assim se saudou a participação dos ginastas no evento: "Honra aos dignos amadores e professores que assim cooperam para o triumfo e vitória da mais santa das causas". ${ }^{2}$

$\mathrm{Na}$ agremiação, aliás, foi fundado o Centro Abolicionista Forense, formado por "trabalhadores modestos" ${ }^{3}$ que "unindo-se à Confederação será uma grande força para a propaganda do bem". .54 No ano seguinte, em 1884, também nas dependências do Clube Ginástico, criou-se um grupo exclusivamente formado por portugueses e seus filhos, o Centro Português Redentor dos Escravos. ${ }^{55}$ Para o Campeão Lusitano, era um passo esperado, já que muitos da colônia estavam envolvidos com a causa, uma prova da sua "virilidade" e "aspiraçôes generosas". ${ }^{56}$

Não surpreende, assim, que o clube tenha tomado parte ativa nas comemoraçóes da aboliçáo da escravatura. Nas festividades realizadas no Campo da Aclamação, participou com sua banda de música, seus alunos de ginástica e dois carros com estandartes. ${ }^{57}$

Mais um indicador das atividades políticas que sediou o Clube Ginástico: em fevereiro de 1887, anunciou-se que Adolfo Bezerra de Menezes, um antigo sócio, convidou "os liberais do município neutro, para tratarem da organização do partido", reuniáo realizada nas dependências da agremiação. ${ }^{58}$ Esse importante personagem do Império se notabilizou pelo caráter empresarial de suas iniciativas, pela defesa de ideais liberais, pelo combate à escravidáo, pela preocupação com os mais carentes e por ser um dos líderes da doutrina espírita no Brasil.

Por vezes as reuniôes tinham relação com a política de Portugal. Em abril de 1881, dirigido por Francisco Travassos Valdez, que viajara pelo continente africano como explorador, houve um encontro para tratar de um assunto que deixava de "sobressalto o espírito dos portugueses", ${ }^{59}$ o Tratado de Lourenço Marques, proposto pelos britânicos, que permitiria à sua marinha manter-se em águas moçambicanas e desembarcar no porto da capital. $\mathrm{O}$ acordo não foi ratificado pelo parlamento português, desencadeando uma crise diplomática. A participação foi ampla: a colônia portuguesa desejava ser esclarecida para ajudar no que fosse necessário.

\footnotetext{
${ }^{51}$ Gazeta de Notícias, 1ํ maio 1881. p. 2.

${ }^{52}$ Id., 8 maio 1881. p. 3.

${ }^{53} \mathrm{O}$ grupo era formado majoritariamente por advogados (logo, trabalhadores nem táo modestos). Para mais informações e um debate sobre a relação entre associativismo e abolicionismo, ver: ALONSO, Angela. Associativismo avant la lettre — as sociedades pela abolição da escravidão no Brasil oitocentista. Sociologias, Porto Alegre, ano 13, n. 28, p. 166-199, set./dez. 2011.

${ }^{54}$ Gazeta da Tarde, 15 dez. 1883. p. 2.

${ }^{55}$ Gazeta de Notícias, 7 abr. 1884. p. 2.

${ }^{56}$ Campeão Lusitano, 26 abr. 1884. p. 3. Esse periódico era ligado à colônia portuguesa; seu perfil foi debatido na introdução (ver notas 1, 2 e 4).

${ }^{57}$ Gazeta de Notícias, 21 e 22 maio 1888. p. 1.

${ }^{58}$ Diário de Notícias, 27 fev. 1887. p. 1. Esse periódico foi um dos que mais fortemente se engajou nas campanhas republicanas, destacando-se a atuação de Rui Barbosa.

${ }^{59}$ Gazeta de Notícias, 8 abr. 1881. p. 2.
} 
Anteriormente, Valdez já proferira uma conferência narrando e enfatizando a importância das expediçóes de Serpa Pinto, um dos responsáveis por reconhecer, mapear e tomar posse de terras de Portugal na região de Angola. ${ }^{60} \mathrm{O}$ próprio Serpa Pinto esteve no Brasil e recebeu muitas homenagens da colônia portuguesa e do Clube Ginástico. Entre outras atividades, promoveu-se em sua honra, em junho de 1881, um baile. Os salóes foram ornados com muito luxo e muitos símbolos que remetiam a sua experiência na África, bem como às coroas de Brasil e Portugal. ${ }^{61}$

Os eventos de Valdez e Serpa Pinto referiam-se a uma preocupaçáo constante no Portugal daquele momento, a manutençáo de suas terras em África, que deveriam ser definitivamente ocupadas para que não se perdessem em um momento de expansão colonial. Várias potências procuravam tomar posse de territórios no continente, um movimento que teve como marca importante a Conferência de Berlim, na qual os portugueses participaram de forma secundária. ${ }^{62}$ Mesmo distantes de seu país de origem, os lusitanos no Brasil estabelecidos procuravam acompanhar e de alguma forma contribuir com os interesses da nação ibérica.

Se o Clube Ginástico logrou sucesso desde os seus momentos iniciais, sua trajetória também foi marcada por conflitos internos, ligados aos diferentes interesses que, em certa medida, expressavam fraturas na heterogênea colônia portuguesa. Quem deveria ser aceito como sócio? A qual rede de relaçóes vincular-se-ia a agremiação? Essas questôes estiveram na base de certas tensôes que, em boa medida, foram responsáveis pela criação do Congresso Ginástico Português.

Vejamos alguns indícios desses conflitos. Em dezembro de 1875, um jornalista critica com veemência as açôes de Viridiano de Carvalho, chamando-o de "serpente venenosa" e "verme roedor", ${ }^{63}$ considerando-o alguém que não mereceria privar da convivência de cavalheiros, senhoras e famílias. O que motivara tamanha fúria? Em reunião da diretoria do Clube Ginástico, Carvalho chamara de "lavadeiras" e "biqueiras" as jovens de uma agremiação que fora convidada para um baile, o Flor dos Alpes, uma sociedade dançante mais popular.

Para o cronista, Viridiano cometia equívocos imperdoáveis ao julgar as famílias pelo traje e ao ofender as mulheres. Ele teria desrespeitado a proposta, o clima e os intuitos do clube. Por isso, a sugestão de que fosse excluído do convívio, para que não mais envergonhasse a agremiação. Todavia, Carvalho não só não foi expulso, como ainda ampliou seu prestígio. Sua posição, de fato, repercutia o que pensavam outros sócios: a reivindicação por maior elitização.

${ }^{60}$ Gazeta da Noite, 14 jul. 1879. p. 1.

${ }^{61}$ Gazeta da Tarde, 28 jun. 1881. p. 1.

${ }^{62}$ PIMENTA, Fernando Tavares. Portugal e o século XX: Estado-Império e descolonização (1890-1975). Lisboa: Afrontamento, 2010.

${ }^{63}$ A Reforma, 7 dez. 1875. p. 3. Esse periódico defendia um programa liberal para o país, caracterizando-se por posiçóes convictas e enfáticas. Chegou a ser um dos mais lidos e influentes da capital (SODRÉ, Nelson Werneck. História da imprensa no Brasil, op. cit.). 
Português de nascimento, autor de importantes livros de ensino comercial, Viridiano atuou em muitas casas, tornando-se famoso guarda-livros. Chegou a trabalhar no Jornal do Commercio e a ocupar cargos no governo republicano. ${ }^{64}$ No âmbito do clube, foi o introdutor das atividades dramáticas, origem de uma das maiores vocaçóes da agremiação, materializada no futuro em um importante grupo cênico e em um dos teatros de referência da cidade (o Teatro Ginástico, que existe até os dias de hoje).

Certamente tratou-se de uma iniciativa que ampliou o perfil do Clube Ginástico, sendo por diversas vezes celebrada: "O encanto da beleza congraçava-se com a ufania da mocidade e a arte dramática abraçando-se com a ginástica, deu horas de verdadeiro prazer" ${ }^{65}$ No decorrer do tempo, as atividades dramáticas foram ganhando espaço. Passaram até mesmo a ser promovidos saraus dramático-dançantes nos quais não havia espaço para os exercícios ginásticos. ${ }^{66}$

A posição de Viridiano era também um indício das tensóes relacionadas à direção da entidade, problemas que começaram alguns anos antes. A diretoria tomara algumas decisóes polêmicas, como exclusão de sócios, restrição à possibilidade de associação, proibição de entrada de convidados em determinados eventos, cobrança mais amiúde de inadimplentes. Essas posturas desagradaram muitos filiados, alguns dos quais acabaram por se desligar e se transferir para o Congresso Ginástico.

Esses conflitos explicitaram-se nas eleiçóes para a diretoria de 1876, um debate perceptível nos jornais. Alguém que assina como "Um sócio imparcial" defende a candidatura a presidente de Inácio Ferreira Nunes ${ }^{67}$ para ele "competente para fazer cessar certo desequilíbrio que se nota na marcha da associaçáo" ${ }^{68}$ No dia seguinte, o mesmo autor publica uma carta ainda mais longa, explicitando os motivos de sua posição, notadamente os avanços que o indicado teria propiciado ao clube quando integrou a direção.

Inácio Ferreira Nunes saiu-se vencedor nas eleiçóes e parece ter alcançado boa parte de seus objetivos à frente da direção. No final de sua gestão, ele foi enfaticamente saudado, sendo agraciado, "pelos serviços prestados ao club", com a "venera do hábito da Conceição de Vila Viçosa", ${ }^{69}$ investido pelo próprio barão de Wildik. Em linhas gerais, promoveu um maior investimento nas atividades internas (maior número de reunióes familiares), uma escolha mais cuidadosa dos contatos com outras sociedades, uma maior sofisticação do funcionamento da agremiação, confirmando a tendência de elitização.

\footnotetext{
${ }^{64}$ SILVA, Amado Francisco da. A contabilidade brasileira no século XX- leis, ensino e literatura. Dissertação (Mestrado em Ciências Contábeis e Financeiras), Pontifícia Universidade Católica de São Paulo, São Paulo, 2005.

${ }^{65}$ O Mequetrefe, n. 99, 1877, p. 6.

${ }^{66}$ Desde a fundação do clube, e no decorrer do século, houve sempre apresentações de exercícios ginásticos integrando a programação dos bailes e saraus.

${ }^{67}$ Comerciante e fabricante do ramo de cigarros, maçom, já dirigente de outras agremiaçóes portuguesas, como a Caixa de Socorros de D. Pedro V, ocupara anteriormente cargos no Clube Ginástico.

${ }^{68}$ Diário do Rio de Janeiro, 9 nov. 1876, p. 3.

${ }^{69}$ Gazeta de Notícias, 27 maio 1879. p. 2. Trata-se de uma antiga e honrosa ordem portuguesa.
} 
Associativismo e política no Rio de Janeiro do Segundo Império: o Clube Ginástico Português E o Congresso Ginástico Português

Victor Andrade de Melo e Fabio de Faria Peres

Vejamos, por exemplo, esse adendo ao anúncio de uma festa de aniversário do clube, um indício dos novos rigores que passaram a cercar o seu funcionamento:

\section{AVISO ESSENCIAL}

A diretoria desejando dar a esta solenidade todo o esplendor que o ato impóe, pede aos Srs. sócios todo o rigor na toillete; assim como reserva-se o direito de proibir a entrada a pessoas agregadas, cavalheiros, ou famílias cujo chefe não seja o designado no cartáo apresentado.

Não serão também admitidas crianças menores de 5 anos. $^{70}$

Se a princípio a frequência aos bailes influenciou na gestação de uma nova moda, uma forma de se vestir mais leve e menos formal, posteriormente desenvolveu-se uma série de princípios mais rigorosos para quem frequentasse essas atividades sociais, especialmente para as mulheres. Conforme a cidade se "civilizava" também se desenvolviam preocupações e iniciativas relacionadas ao "bem trajar-se". Os eventos públicos eram uma ocasião para que se demonstrasse a sintonia com o "bom gosto", representava de representar uma oportunidade de diferenciação social.

Um interessante indício dessas mudanças é a coluna "Modas", assinada por Jeane Teduar, que ocupava a seção folhetim do Diário Portuguez. Em certa ocasião, inferindo que "minhas formosas leitoras estão se preparando para o próximo baile do Real Club Ginástico Português", ${ }^{71}$ ofereceu uma série de sugestóes de vestimentas. Mais ainda, no final "ameaça": "terei ocasião de ver se se dignaram a prestar atenção aos meus conselhos".

As mudanças promovidas a partir de meados da década de 1870 náo aplainaram todos os conflitos internos e não resolveram definitivamente os problemas financeiros da agremiação. Parece que, de alguma forma, o Clube Ginástico registrou o impacto da criação do outro grupo de cariz português: o Congresso Ginástico Português.

\section{Congresso Ginástico Português}

O Congresso Ginástico Português foi fundado em 1874, tendo origem nas divergências internas do Clube Ginástico Português. Instalou-se na rua do Núncio, no terreno ao lado da sede do congênere lusitano. Como se pode perceber em seus primeiros estatutos, ${ }^{72}$ nos momentos iniciais tinha um perfil semelhante ao do clube rival. Com a aprovação dos segundos

\footnotetext{
${ }^{70}$ Id., 27 out. 1881. p. 3.

${ }^{71}$ Diário Portuguez, 5 abr. 1885. p. 1. Esse periódico era ligado à colônia portuguesa; seu perfil foi debatido na introdução (ver notas 1,2 e 4).

72 BRASIL. Decreto $n^{0}$ 5.873, de 13 de fevereiro de 1875. Aprova os estatutos da Sociedade denominada Congresso Ginástico Português. Disponível em: <www2.camara.leg.br/legin/fed/decret/1824-1899/decreto-5873-13-fevereiro-1875-549848-norma-pe.html>. Acesso em: 6 jun. 2013.
} 
Associativismo e política no Rio de Janeiro do Segundo Império: o Clube Ginástico Português E o Congresso Ginástico Português

Victor Andrade de Melo e Fabio de Faria Peres

estatutos, em 1879, ${ }^{73}$ estabeleceram-se de forma mais explícita as diferenças, mantendo-se o Congresso mais fortemente relacionado com os comerciários, uma clara tentativa de evitar (ou mesmo se contrapor a) um processo de elitização.

Náo se pode com certeza dizer que era "popular" o Congresso, no sentido de garantir o acesso a estratos sociais considerados menos abastados ou de menor prestígio. Deve-se destacar, de toda forma, que em sua trajetória a agremiação não frequentou a mesma esfera social do Cassino Fluminense e do Clube Ginástico, mantendo relaçóes mais próximas com sociedades menos ligadas à grande elite, tais como os Fenianos, os Tenentes do Diabo, os Girondinos e o Congresso Brasileiro.

Esse perfil diferenciado por vezes foi sublinhado pelos jornais, como nessa notícia publicada na coluna "Semana Teatral", no folhetim da Gazeta de Notícias. Ao falar de um sarau no clube realizado, o cronista o considera mais simples, ainda que náo menos divertido: "mais democrática e de caráter mais popular, teve a festa do Congresso o encanto da mais bela confraternidade". ${ }^{74}$

Outro interessante indicador das diferenças é o perfil das agremiaçôes para as quais o Congresso cedeu seus salóes para reuniōes, distinto daquelas que utilizavam o Clube Ginástico. Por suas instalaçóes também passaram algumas importantes questóes políticas do Segundo Império, todavia houve mais encontros de associaçóes de categorias de trabalhadores bastante ativos, como é o caso do Grêmio Tipográfico e da Sociedade Auxiliadora de Artistas Alfaiates. ${ }^{75}$

Outra associação semelhante, a Imperial Associação Tipográfica Fluminense, uma das pioneiras entidades sindicais do país, ${ }^{76}$ no Congresso promoveu uma festa artística, em novembro de 1881,77 em conjunto com a Associação Central Emancipadora, que entre seus integrantes contava com personalidades como André Rebouças e José do Patrocínio. ${ }^{78}$ Essa sociedade realizou muitos eventos no clube, parte de sua campanha abolicionista.

O Congresso também acolheu muitas iniciativas ligadas à abolição da escravatura. A Sociedade Abolicionista Cearense promoveu duas grandes festas nos salóes do clube português. Na primeira, em 1883, comemorou-se a libertação dos escravos em Fortaleza. ${ }^{79}$ No ano se-

\footnotetext{
73 BRASIL. Decreto $n^{\circ}$ 7.533, de 28 de outubro de 1879. Aprova os novos estatutos da sociedade Congresso Ginástico Português. Disponível em: <www2.camara.leg.br/legin/fed/decret/1824-1899/decreto-7533-28-outubro-1879-548806-norma-pe.html>. Acesso em: 6 jun. 2013.

${ }^{74}$ Diário do Rio de Janeiro, 21 jun. 1877. p. 1.

${ }^{75}$ Para mais informaçóes sobre essas agremiaçóes, ver: LACERDA, David Patrício. Solidariedade entre ofícios: a experiência mutualista no Rio de Janeiro imperial (1860-1882). Dissertação (mestrado em história) — Universidade de Campinas, Campinas, 2011.

${ }^{76}$ Para mais informaçôes, ver: MATTOS, Marcelo Badaró. Trabalhadores escravizados e livres na cidade do Rio de Janeiro na segunda metade do século XIX. Revista Rio de Janeiro, Rio de Janeiro, v. 12, p. 229-251, 2004.

77 Gazeta da Tarde, 18 nov. 1881. p.1.

${ }^{78}$ Para mais informaçóes, ver: ALONSO, Angela. Associativismo avant la lettre, op. cit.

${ }^{79}$ Gazeta da Tarde, 21 maio 1883. p. 3.
} 
Associativismo e política no Rio de Janeiro do Segundo Império: o Clube Ginástico Português E O CONGRESSO GinÁstico PORTUguês

Victor Andrade de Melo e Fabio de Faria Peres

guinte, os festejos foram ainda maiores: oito dias de celebração pela abolição da escravatura na província do Ceará. ${ }^{80}$ Nessas cerimônias, o Congresso foi coberto de elogios e saudaçôes por sua ajuda à causa.

O clube também acolheu algumas reunióes do Centro Positivista. Em uma dessas ocasiōes, em comemoração à independência, foram promovidas conferências de Teixeira Mendes ${ }^{81}$ um dos líderes do positivismo no Brasil, movimento que estava engajado na luta abolicionista e construindo condições para a proclamação da república. ${ }^{82}$

A agremiação chegou a acolher, em 1881, uma conferência de Carlos Augusto do Carvalho, na ocasiáo candidato à Assembleia Geral Legislativa, republicano que futuramente assumiria importantes cargos governamentais, se destacando por sua atuação na política externa (chegou a ser ministro do Exterior de Floriano Peixoto).

Desde 1882, antes, portanto, do que no Clube Ginástico, o Congresso cedia espaço para reuniôes dos liberais, convocadas pelo já citado Bezerra de Menezes. Nesse ano, a reunião de avaliação das açóes do Partido Liberal contou com a presença de importantes personagens do Império, como Silveira Martins. O debate era sobre que posição adotar diante do governo, alguns propondo explicitar a oposição.

Enfim, assim como no Clube Ginástico, ainda que com perfil diferenciado, percebe-se como o Congresso Ginástico esteve imbricado nas interseçôes entre as causas republicanas e abolicionistas. As duas associaçôes refletiram as divisões políticas do contexto, inclusive internas aos próprios movimentos, sem, no entanto, aderir oficialmente a um partido. Tratava-se, antes de tudo, de uma posição de simpatia e apoio que tinha a ver com o perfil de seus sócios.

Se considerarmos a diferença de perfil entre o Congresso e o Clube Ginástico, vale perguntar como teria a nova agremiação se relacionado com a própria colônia portuguesa. Em vários momentos, nos primeiros anos de existência, sua forma de funcionamento causou surpresas. Um exemplo pode ser observado quando do falecimento do escritor Alexandre Herculano, fato que causou consternação entre os lusitanos que viviam no Rio de Janeiro. Enquanto as sociedades de cariz português fecharam suas portas, em sinal de luto, o Congresso, nas palavras de um sócio, que indignado se desligaria do clube, "cobriu-se de galas e ofereceu um baile aos seus associados!! É vergonhoso, mas é verdade!!”. ${ }^{3}$

Para o autor da missiva, embora aceitasse sócios de todas as nacionalidades, o Congresso não poderia negar sua ligaçâo com a colônia portuguesa. Nesse sentido, não era aceitável

${ }^{80}$ Gazeta de Notícias, 21 mar. 1884. p. 6.

${ }^{81}$ Gazeta da Tarde, 7 set. 1881. p. 2.

${ }^{82}$ A trajetória do movimento positivista, todavia, não foi unidimensional, havendo várias dissensões. Para um debate, ver: MELO, Rafael Reis Pereira Bandeira de. A militância do Apostolado Positivista do Brasil em favor da abolição da escravidão por intermédio de opúsculos e correspondências (1881-1888). In: ENCONTRO REGIONAL DE HISTÓRIA DA ANPUH-RIO, 15, 2012, Rio de Janeiro. Anais... Rio de Janeiro: Anpuh, 2012. (Anais eletrônicos).

${ }^{83}$ Gazeta de Notícias, 3 dez. 1877. p. 2. 
Associativismo e política no Rio de Janeiro do Segundo Império: o Clube Ginástico Português E o Congresso Ginástico Português

Victor Andrade de Melo e Fabio de Faria Peres

tal procedimento. É cruel a sua avaliação sobre as causas da manutenção do baile: "Sei que a totalidade dos sócios dessa associação é quase analfabeta e por consequência incapaz de avaliar o mérito do nosso escritor". ${ }^{84}$

Dias depois, um associado do Congresso respondeu às acusações, tentando justificar a decisão da diretoria. Mostra-se indignado com o tratamento dado à agremiação, contestando os argumentos do sócio que se desligava. Ele lembrou que o baile já estava programado antes da morte de Herculano, defendendo por isso a manutenção da atividade: "Só nos inspira dó, quem transpôs as regras de civilidade, para fingir sentimentos nobres. Infelizmente os carolas abundam como átomos no espaço". ${ }^{55}$ Além disso, recordava que o Congresso integrava uma comissão fundada com o intuito de homenagear o escritor e garantir conforto para a sua família.

Vale a pena deslindar o conjunto de temas que se manifestou nessas posiçóes. Inegavelmente, tendo em conta os padróes do momento, quando o luto era algo muito valorizado, manter o baile tratou-se de um procedimento destoante, tanto mais por se tratar de alguém importante para a colônia portuguesa. De outro lado, a reação é um indicador de que preconceitos poderiam cercar o Congresso, em função de uma composição societária mais popular.

Além disso, o sócio que se desligou manifestou incômodo diante da postura "pouco lusitana" do Congresso. De fato, tirando os costumeiros apoios beneficentes, durante um bom tempo percebemos uma relação menos intensa com os símbolos portugueses, bem mais tênue do que a observada no Clube Ginástico.

De toda maneira, ainda que menos frequentemente do que no Clube Ginástico, personalidades da colônia portuguesa também em algum momento compareceram a alguma atividade pelo Congresso promovida. Além disso, a agremiação chegou a receber certo reconhecimento de alguns veículos ligados a Portugal: "É para nós de subida congratulação a bizarria com que esta benemérita e patriótica sociedade honra nesta o nome português" ${ }^{86}$

O Congresso mantinha relaçóes mais próximas com o Retiro Literário Português, enquanto o Clube Ginástico, com o Liceu Literário e com o Real Gabinete Português de Literatura. O Retiro fora fundado em 1859, enquanto o Liceu, a partir de uma dissidência, em 1868.

A única referência encontrada acerca de uma suposta rivalidade entre as agremiaçóes literárias portuguesas foi no estudo de Tavares, Silva e Castro Filho ${ }^{87} \mathrm{O}$ Liceu oferecia uma escola noturna gratuita para portugueses e brasileiros, mas seu grupo societário era mais afeito aos que frequentavam o Clube Ginástico. Talvez seja possível considerar ambos como mais ligados aos estratos economicamente superiores da colônia portuguesa.

\footnotetext{
${ }^{84}$ Ibid.

${ }^{85}$ Id., 9 dez. 1877, p. 2.

${ }^{86}$ Gazeta Lusitana, 13 e 14 ago. 1884. p. 3.

${ }^{87}$ TAVARES, António Rodrigues; SILVA, Pedro Ferreira da; CASTRO FILHO, Manoel Ferreira de. Fundamentos e atualidade do Real Gabinete Português de Leitura. Rio de Janeiro: RGPL, 1977.
} 
De fato, entre as agremiaçóes ginásticas muitos foram os episódios de rivalidade. Alguns deles chegaram a se manifestar mesmo em eventos beneficentes, notadamente naqueles promovidos por agremiaçôes da colônia, como ocorreu por ocasiáo de um dos aniversários da Beneficência Portuguesa, realizado em 1876.

O colunista de $O$ Mosquito não deixou passar despercebidos os conflitos: "As eleições, as urnas, o terço liberal e o terço conservador, as mesas e os subdelegados, não se falaria agora em outra cousa, se a propósito de donativos feitos à Beneficencia Portugueza, dois clubs ginásticos não estivessem fazendo gemer os prelos, atirando piadas um ao outro". ${ }^{88}$

O cronista elogia os clubes por sua postura, abandonar "momentaneamente o trapézio para irem praticar um ato de generosidade", mas pondera que "andarem num dize tu, direi eu, que parece quererem engulir-se", acaba por macular a imagem da ginástica, que, segundo ele, com ironia, começa a ser reconhecida por sua importância: "Com efeito assim o exigem as nossas canelas obrigadas a saltos mortais por quantos bonds, carros e carroçóes aí nos atropelam por essas ruas, com grande gáudio dos Srs. doutores, que têm onde se entreter enquanto não chega a febre amarela”.

Em 1877, as rivalidades de novo chegam aos jornais por meio de mensagens cifradas. Um português, que não assina a nota, recém-chegado ao Rio de Janeiro, observa: "sinto de todo coração que se dê essas cenas lamentáveis entre a família portuguesa". ${ }^{99}$ Um anônimo, que depois sabemos ligado ao Clube Ginástico, convocou ironicamente, em tom bélico, um ataque à sede do Congresso. ${ }^{90}$ Alguns dias depois, outro anônimo, ligado aos Tenentes do Diabo, critica a mensagem e deixa claro: "Os Tenentes não tem nada com a discórdia que existe entre o Congresso e o Club". ${ }^{11}$ Essas mensagens tinham em conta a convocatória que a agremiação da rua do Núncio fizera para dois bailes a fantasia, ambos destinados a também arrecadar recursos para vítimas da inundação em Portugal.

Essas tensões também se manifestaram ao redor das modalidades esportivas/ginásticas. Por exemplo, quando o Clube de Regatas Guanabarense, um dos mais importantes do remo brasileiro, organizou pela primeira vez um páreo náutico para as sociedades ginásticas, em 1881, a guarnição do Congresso foi eliminada por supostamente ser formada por "profissionais" (marinheiros e catraieiros).

Para a diretoria do Congresso, que refutou de forma indignada as acusaçôes, não havia dúvidas de que se tratava de uma intriga do rival português: "É nojento! É asqueroso! Oh, cobardia! Ó inveja, a quanto obrigas!.. (...) Felizmente o Congresso não necessita de puffs para se elevar! O Club que bufe! Que zurre!”.92

\footnotetext{
${ }^{88}$ O Mosquito, 14 out. 1876. p. 6.

${ }^{89}$ Gazeta de Notícias, 24 jan. 1877. p. 3.

${ }^{90}$ Id., 4 fev. 1877 , p. 2.

${ }^{91}$ Id., 8 fev. 1877. p. 2.

${ }^{92}$ Id., 9 set. 1881. p. 2.
} 
No ano seguinte, o conflito envolveu as aulas de ginástica e o nome do mestre Vicente Casali, que lecionava nas duas agremiaçôes. Alguns sócios do Clube Ginástico denunciaram que o professor os desprestigiava e levava alunos para o rival. Essa tensão já se tornara aparente no início do mês de dezembro, quando, lado a lado, na mesma página da Gazeta de Notícias, fora publicado um grande elogio e uma crítica ao referido docente. ${ }^{93}$

Pelos jornais se chegou a sugerir que a diretoria do Clube Ginástico deveria demitir Casali. Esse, por sua vez, refutou enfaticamente as acusaçôes, considerando-as maledicências que intentavam prejudicar sua imagem..$^{94}$ De toda forma, o mestre seguiu atuando no Clube Ginástico até 1885, e no Congresso até 1891.

Nos anos finais do Império, o Congresso passou a mais enfaticamente demonstrar sua ligação com a colônia e com os símbolos de Portugal. Na verdade, sempre foi um clube de cariz português; diferente do Clube Ginástico, mas não menos português. Mais do que traços distintos no que tange a demonstraçôes de fidelidade à pátria de origem, cada associação reunia grupos que, à sua maneira, se arrogavam portadores privilegiados do que consideravam como éthos lusitano.

Se a elite portuguesa, conforme aponta Marie-Jo Ferreira, ${ }^{95}$ se dedicou a desvanecer as diferenças sociais, políticas e econômicas por meio de um discurso de comunhão em torno de uma suposta identidade nacional portuguesa, a experiência social das agremiaçóes permite entrever cisóes e os limites desse discurso.

Esses conflitos entre o Congresso e o Clube Ginástico, portanto, nos ajudam a perceber algo pouco discutido: mais do que rivalidades entre brasileiros e portugueses, havia fraturas na colônia lusitana, que se integrava de forma heterogênea ao país que estava nascendo e se forjando como ente independente.

\section{À guisa de conclusão}

Depois de mais de uma década de tensão, nos anos finais do Império estabeleceu-se uma maior relação entre as duas sociedades ginásticas de portugueses. Vemos um indício disso no dia seguinte a um passeio campestre realizado pelos sócios do Congresso no Jardim Botânico. A diretoria publicou nos jornais o seguinte agradecimento:

À nossa digna coirmã Real Club Ginástico Português, de quem preconceitos de ocasião que o tempo fez desaparecer nos tornaram indiferentes, o Congresso agradece a inesperada surpresa da prova de confraternizaçáo que nos esperava ao passarmos em frente ao seu edifício,

\footnotetext{
${ }^{93}$ Id., 3 dez. 1882. p. 3.

${ }^{94}$ Id., 28 e 29 dez. 1882. p. 2.

${ }^{95}$ FERREIRA, Marie-Jo. Os portugueses do Brasil, atores das relaçôes luso-brasileiras, fim do século XIX — inicio do século $X X$, op. cit.
} 
Associativismo e política no Rio de Janeiro do Segundo Império: o Clube Ginástico Português e o Congresso Ginástico Português

Victor Andrade de Melo e Fabio de Faria Peres

iluminando a sua frente e vindo com seu estandarte ao meio do nosso préstito saudar-nos e estender-nos a mão de amigo, convidando-nos a entrar no seu saláo. Que o laço de amizade, selado na mais íntima alegria, perdure, são os votos que fazemos ao agradecer as provas de amizade que recebemos. ${ }^{96}$

Mais um encontro entre os clubes ocorreria por ocasiáo do 15a aniversário do Congresso, em 1889, ${ }^{97}$ uma ocasião muito festejada. Essa confraternização vinha bem a calhar. A República estava para chegar e levaria as relaçôes entre Brasil e Portugal para um dos seus piores momentos, ${ }^{98}$ algo que traria desdobramentos para a colônia portuguesa no país:

É na última década do século XIX e nas duas primeiras do seguinte que se adensam as tensōes entre portugueses e nacionais, inscrevendo no imaginário social novas formas de rejeição. Assim, à antiga e desgastada imagem do português, visto pela população brasileira como o explorador/colonizador/patrāo, acrescenta-se a de estrangeiro/monarquista/conspirador. ${ }^{99}$

De toda forma, no decorrer do Segundo Império, a despeito das diferenças entre os dois clubes, houve algumas similaridades, entre as quais um certo ativismo: se não necessariamente uma vinculação direta, pelo menos uma acolhida bem simpática de algumas iniciativas políticas de grande importância na ocasião.

Lembremos, aliás, que o Congresso seguiu sendo um local de certa movimentação política. Já no primeiro momento do novo regime, sediou a reunião de um conjunto de personalidades republicanas que desejavam "cooperar nos trabalhos de reconstituição de nossa Pátria e convindo, de modo eficaz e permanente, estabelecer as correntes de opiniáo, que auxiliem o Governo provisório e o do Estado do Rio de Janeiro na direção dos negócios políticos" ${ }^{100}$

A reunião acabou não acontecendo, em função das tensôes do momento. Ocorreu sim a do Centro Federativo 15 de novembro, pessoas de "várias nacionalidades", notadamente estrangeiros que no Brasil viviam, ligados à classe do comércio, que pretendiam homenagear o novo governo, inclusive com a construção de uma estátua para Deodoro. ${ }^{101} \mathrm{Um}$ dos temas tratados foi da "grande naturalizaçáo": ${ }^{102}$ o novo governo pretendia naturalizar todos os estrangeiros que explicitamente não manifestassem o desejo de manter a nacionalidade de origem.

Esse novo cenário talvez tenha sido mesmo um dos responsáveis por encerrar os conflitos entre o Congresso e o Clube Ginástico. De toda maneira, logo surgiriam novas agremiaçóes

\footnotetext{
${ }^{96}$ Diário de Notícias, 10 jul. 1889. p. 3.

${ }^{97}$ Diário do Commercio, 18 ago. 1889. p. 2.

${ }^{98}$ CERVO, Amado Luiz; MAGALHÂES, José Calvet de. Depois das caravelas, op. cit.

${ }^{99}$ SILVA, Maria Manuela de R. de Sousa. Portugueses no Brasil, op. cit. p. 115.

${ }^{100}$ Cidade do Rio de Janeiro, 29 nov. 1889. p. 2.

${ }^{101}$ Diário de Notícias, 22 dez. 1889. p. 1.

${ }^{102}$ Id., 23 dez. 1889. p. 2.
} 
recreativas de cariz português, entre as quais uma que será muito reconhecida pelos lusitanos que viviam no Rio de Janeiro: o Vasco da Gama, fundado em 1898. Posteriormente, seriam ainda fundadas importantes congêneres: o Clube de Regatas Guanabara (1899, uma dissidência do Vasco), o Lusitânia Futebol Clube (1915) e a Associação Atlética Portuguesa (1924).

Devemos também lembrar que muitas dessas estariam ligadas às diversas regiôes de Portugal. Agremiaçóes como a Casa das Beiras, Casa do Minho e Casa dos Poveiros, entre tantas outras, foram importantes por agrupar portugueses no Brasil estabelecidos, mas também, por dividir a colônia, acabaram por enfraquecer os dois clubes ginásticos pioneiros.

O Clube Ginástico Português segue vivo e ativo até os dias de hoje. Sua sede atual, na avenida Graça Aranha, é a mesma que foi construída em 1938, no mesmo centro da cidade que sempre o abrigou. Para lá o clube foi quando se incendiou sua sede da rua do Hospício, em 1934.

Já o Congresso não resistiu ao tempo. Em 1898, percebemos pelos jornais que já estava com pouca atividade. Em 1899, somente conseguimos uma referência nos periódicos. Em 1900, a Fábrica a Vapor de Caixas de Papeláo Cancio \& Irmão anuncia que mudara de sede, da rua do Lavradio para o "conhecido palacete do antigo Congresso Ginástico Português". ${ }^{103}$ Estava encerrada a trajetória do clube.

${ }^{103}$ Cidade do Rio Janeiro, 13 fev. 1900. p. 4. 